

\title{
Assessment of the potential genotoxic risk of medicinal Tamarindus indica fruit pulp extract using in vivo assays
}

\author{
F.M.V. Silva ${ }^{1}$, M.F. Leite ${ }^{2}$, A.C.C. Spadaro ${ }^{2}$, S.A. Uyemura ${ }^{3}$ and \\ E.L. Maistro ${ }^{4}$ \\ ${ }^{1}$ Laboratório de Genética, Universidade José do Rosário Vellano, \\ Alfenas, MG, Brasil \\ ${ }^{2}$ Departamento de Física e Química, Faculdade de Ciências Farmacêuticas, \\ Universidade de São Paulo, Ribeirão Preto, SP, Brasil \\ ${ }^{3}$ Departamento de Análises Clínicas, Toxicológicas e Bromatológicas, \\ Faculdade de Ciências Farmacêuticas, Universidade de São Paulo, \\ Ribeirão Preto, SP, Brasil \\ ${ }^{4}$ Departamento de Fonoaudiologia, Faculdade de Filosofia e Ciências, \\ Universidade Estadual Paulista, Marília, SP, Brasil
}

Corresponding author: E.L. Maistro

E-mail address: edson.maistro@marilia.unesp.br

Genet. Mol. Res. 8 (3): 1085-1092 (2009)

Received April 28, 2009

Accepted June 24, 2009

Published September 8, 2009

\begin{abstract}
Tamarindus indica has been used in folk medicine as an antidiabetic, a digestive aid, and a carminative, among other uses. Currently, there is no information in the toxicology literature concerning the safety of $T$. indica extract. We evaluated the clastogenic and/or genotoxic potential of fruit pulp extract of this plant in vivo in peripheral blood and liver cells of Wistar rats, using the comet assay, and in bone marrow cells of Swiss mice, using
\end{abstract}


the micronucleus test. The extract was administered by gavage at doses of 1000, 1500 and $2000 \mathrm{mg} / \mathrm{kg}$ body weight. Peripheral blood and liver cells from Wistar rats were collected $24 \mathrm{~h}$ after treatment, for the comet assay. The micronucleus test was carried out in bone marrow cells from Swiss mice collected $24 \mathrm{~h}$ after treatment. The extract made with $T$. indica was devoid of clastogenic and genotoxic activities in the cells of the rodents, when administered orally at these three acute doses.

Key words: Tamarindus indica; Micronucleus test; Comet assay; Medicinal plant; Single-cell gel electrophoresis

\section{INTRODUCTION}

The tamarind (Tamarindus indica L.) is a tree-type plant that belongs to the Leguminosae, Caesalpiniaceae family. It is indigenous to tropical Africa, but has become naturalized in North and South America, in an area from Florida to Brazil. It is also cultivated in subtropical China, India, Pakistan, Indochina, the Philippines, Java, and Spain. Initially, the fruit shows a reddish-brown color, which turns to black or black-brown, becoming more aromatic and sour on ripening. Components of $T$. indica have been used as spices and food ingredients and in snacks. In traditional Thai medicine, the fruit of the tamarind is used as a digestive aid, carminative, laxative, expectorant, and blood tonic (Komutarin et al., 2004). Other parts of the plant show antioxidant (Tsuda et al., 1994; Pumthong, 1999; Martinello et al., 2006), antihepatotoxic (Joyeux et al., 1995), anti-inflammatory (Rimbau et al., 1999), antimutagenic (Ramos et al., 2003), antidiabetic (Maiti et al., 2004), and antiatherosclerosis (Martinello et al., 2006) activities. Landi Librandi et al. (2007) determined the effect of $T$. indica fruit extract on the complement system (CS) in vitro and in vivo; the hydroalcoholic extract increased complement components and complement lytic activity in vitro, but had no effect on the CS in vivo. Additional analysis and efforts to isolate the compounds of the extract that act on the CS could lead to its therapeutic use as an inflammation modulator.

Recently, there has been increasing interest in determining the genotoxicity of complex mixtures from plants with medical uses, because these mixtures may contain toxic and genotoxic compounds. Because $T$. indica extract is currently being evaluated in preclinical trials for its application in the treatment of certain diseases, its genotoxic risk potential was assessed in this study in vivo using single-cell gel electrophoresis (SCGE, comet assay) and micronucleus test.

\section{MATERIAL AND METHODS}

\section{Plant material}

Ripe fruits of Tamarindus indica were collected in the region of Ribeirão Preto, $\mathrm{SP}$, Brazil, and peeled to obtain the pulp used to prepare the extract. Approximately $100 \mathrm{~g}$ of the fruit pulp was placed in a conical flask and soaked at room temperature for 5 days, 
in $400 \mathrm{~mL} \mathrm{70 \%} \mathrm{ethanol} \mathrm{in} \mathrm{water.} \mathrm{The} \mathrm{resulting} \mathrm{extract} \mathrm{was} \mathrm{filtered} \mathrm{through} \mathrm{a} \mathrm{sieve} \mathrm{and}$ rotoevaporated twice, until the alcohol had completely evaporated.

\section{Chemicals}

The agent cyclophosphamide (Sigma, CAS 50-18-0) was used as the DNA damaging agent in the comet assay and micronucleus test using Swiss mice and Wistar rats. It was dissolved in phosphate buffer, $\mathrm{pH} 6$. The other main chemicals were obtained from the following suppliers: normal melting point agarose (Cat. No. 15510-019, Invitrogen), low melting point agarose (Cat. No. 15517-014, Invitrogen), sodium salt $N$-lauroyl sarcosinate (L-5125, Sigma) and ethylenediaminetetraacetic acid (EDTA, Merck).

\section{Animals and assay procedures}

Experiments were carried out with 30 six-week-old (15 females and 15 males) Wistar rats (Rattus norvegicus), weighing approximately $100 \mathrm{~g}$, and 30 twelve-week-old (15 females and 15 males) Swiss mice (Mus musculus), weighing 25-30 g. The animals were acquired from the animal facility of the José do Rosário Vellano University (UNIFENAS). They were kept in polyethylene boxes $(\mathrm{N}=6)$, in a climate-controlled environment $\left(22 \pm 2^{\circ} \mathrm{C}, 55 \pm 5 \%\right.$ humidity $)$ with a 12-h light/dark cycle ( 7 am to $7 \mathrm{pm}$ ). Food (Labina - Purina) and water were available $a d$ libitum. The Animal Bioethics Committee of UNIFENAS, Brazil, approved the present study in March 2005 (protocol number 04A/2005), in accordance with Brazilian law on animal care. The rats and mice were divided into experimental groups of six animals, with three females and three males in each. Tamarindus indica extract was administered in a single dose of $0.5 \mathrm{~mL}$ by gavage, at doses of 1000,1500 , and $2000 \mathrm{mg} / \mathrm{kg}$ body weight, chosen on the basis of our acute toxicity studies in mice, which was higher than $2000 \mathrm{mg} / \mathrm{kg}$. The negative control group received distilled water. The positive control group, received $50 \mathrm{mg} / \mathrm{kg} \mathrm{N}$-nitroso-N-ethylurea.

For the micronucleus test in Swiss mouse cells, the animals were sacrificed $24 \mathrm{~h}$ after treatment and the bone marrow cells from one femur were prepared as recommended by Schmid (1976). All slides were coded, fixed with methanol and stained with Giemsa solution. The cells were blindly scored using a light microscope at 1000X magnification. Two thousand polychromatic erythrocytes (PCE) from each animal were scored. To detect possible cytotoxic effects, the PCE:NCE (normochromatic erythrorytes) ratio in 1000 erythrocytes/animal was calculated.

The comet assay was carried out using the method described by Speit and Hartmann (1999), which is based on the original work of Singh et al. (1988) and includes modifications introduced by Klaude et al. (1996) as well as additional modifications. Twenty-four hours after treatment, peripheral blood leukocytes and liver cells from Wistar rats were sampled. Liver samples were washed in saline solution, in an ice bath. A small portion was transferred to a Petri dish containing $1 \mathrm{~mL}$ Hank's solution, $\mathrm{pH} 7.5$, and then homogenized gently with small pinches. A $10-\mu \mathrm{L}$ aliquot of cells from each animal was mixed with 120 $\mu \mathrm{L} 0.5 \%$ low melting point agarose at $37^{\circ} \mathrm{C}$, and immediately spread on microscope slides pre-coated with $1.5 \%$ normal melting point agarose. Coverslips were added and the slides were allowed to gel at $4{ }^{\circ} \mathrm{C}$ for $20 \mathrm{~min}$. The coverslips were gently removed and the slides were then immersed in cold, freshly prepared lysis solution consisting of $89 \mathrm{~mL}$ of a stock solution $(2.5 \mathrm{M} \mathrm{NaCl}, 100 \mathrm{mM}$ EDTA, $10 \mathrm{mM}$ Tris, $\mathrm{pH}$ adjusted to 10.0 with $\sim 8 \mathrm{~g}$ solid 
$\mathrm{NaOH}, 890 \mathrm{~mL}$ distilled water and $1 \%$ sodium $\mathrm{N}$-lauroyl sarcosinate), plus $1 \mathrm{~mL}$ Triton $\mathrm{X}-100$ (Merck) and $10 \mathrm{~mL}$ DMSO. The slides were protected from light and left to stand at $4^{\circ} \mathrm{C}$ for $1 \mathrm{~h}$. They were then placed in the gel box, positioned at the anode end, and left in a high $\mathrm{pH}(>13)$ electrophoresis buffer $(300 \mathrm{mM} \mathrm{NaOH}-1 \mathrm{mM}$ EDTA, prepared from a stock solution of $10 \mathrm{~N} \mathrm{NaOH}$ and $200 \mathrm{mM}$ EDTA, $\mathrm{pH} 10.0$ ) at $4^{\circ} \mathrm{C}$ for 20 min prior to electrophoresis, to allow the DNA to unwind. The electrophoresis was carried out in an ice bath $\left(4^{\circ} \mathrm{C}\right)$ for $20 \mathrm{~min}$ at $1.25 \mathrm{~V} / \mathrm{cm}$ and $300 \mathrm{~mA}$. The slides were then submerged in a neutralization buffer ( $0.4 \mathrm{M}$ Tris- $\mathrm{HCl}, \mathrm{pH} 7.5)$ for $15 \mathrm{~min}$, dried at room temperature and fixed in $100 \%$ ethanol for $10 \mathrm{~min}$. The slides were dried and stored overnight or longer, before staining. For the staining process, the slides were briefly rinsed in distilled water, covered with $30 \mu \mathrm{L}$ of $1 \mathrm{X}$ ethidium bromide staining solution prepared from a 10X stock $(200 \mu \mathrm{g} /$ $\mathrm{mL}$ ), and coverslipped. The material was evaluated immediately at $400 \mathrm{X}$ magnification, using a fluorescence microscope (Olympus) with a 515-560-nm excitation filter and a 590-nm barrier filter. An aliquot was removed from peripheral blood and liver cell suspensions to determine cell viability. The cell count (one hundred per animal) was performed using light microscopy. Cell viability was determined by Trypan blue dye exclusion. The number of Trypan blue-negative cells was considered to be the number of viable cells. The value for viable cells as the percentage of control was determined by measuring the absolute number of viable, attached (Trypan blue-negative) cells in the treated animals as a percentage of the number of viable cells in the untreated animals. The animals used in this study were sacrificed in a $\mathrm{CO}_{2}$ chamber.

\section{Scoring procedures and data evaluation (comet assay)}

The extent and distribution of DNA damage indicated by the SCGE assay was evaluated by examining at least 100 randomly selected and non-overlapping cells on the slides per animal. These cells were scored visually, according to tail size, into four classes, as follows: i) class 0: no tail; ii) class 1: tail shorter than the diameter of the head (nucleus); iii) class 2: tail length 1 to $2 \mathrm{X}$ the diameter of the head, and iv) class 3 : tail longer than $2 \mathrm{X}$ the diameter of the head. Comets with no heads and images with nearly all DNA in the tail, or with a very wide tail, were excluded from the evaluation because they probably represent dead cells (Hartmann and Speit, 1997). The total score for 100 comets was obtained by multiplying the number of cells in each class by the damage class, ranging from 0 (all undamaged) to 300 (all maximally damaged).

\section{Statistical analysis}

The data obtained in the micronucleus test and SCGE assay were submitted to oneway analysis of variance (ANOVA) and the Tukey-Kramer multiple comparison test (Sokal and Rohlf, 1995), using the GraphPad Instat ${ }^{\circledR}$ software (version 3.01). The results were considered to be statistically significant at $\mathrm{P}<0.05$.

\section{RESULTS AND DISCUSSION}

Properties elicited by plant species have a full range of prospective applications in human healthcare. Herbal remedies and phytotherapy drugs containing active principles are 
currently being developed to protect against electrophile (e.g., free radical) attack on DNA and its widespread outcomes, such as aging and cancer. Even for populations that use herbs traditionally, encouraging the use of species with chemopreventive actions could be helpful as a strategy for improving life expectancy: the costs are significantly lower, herbs usually have little or no toxicity during long-term oral administration, and they are relatively easy to obtain on a large scale. On the other hand, an evaluation of the genetic toxicity potential of these herbal remedies is essential for their safe use by humans, and recent examples of harmful side-effects of some compounds have been described (Andraws et al., 2005).

In the present study, a clastogenic/aneugenic and genotoxic assessment of one complex mixture was present, which was a fruit pulp extract obtained from the T. indica herb. In the micronucleus test and comet assay, no deaths occurred and no abnormal clinical signs were observed in any animal in any of the groups, including both the positive and the negative control groups. The results of the micronucleus test are shown in Table 1. The incidence of micronucleated polychromatic erythrocytes (MNPCEs) in the T. indica-treated Swiss mouse groups with doses of 1000 and $1500 \mathrm{mg} / \mathrm{kg}$ was a little higher than that of the negative control group, and significantly different in the $2000 \mathrm{mg} / \mathrm{kg}$ dose tested $(\mathrm{P}<0.001)$. As expected, a significant increase in the incidence of MNPCEs was observed in the positive control group treated with cyclophosphamide $(\mathrm{P}<0.001)$.

Table 1. Number of micronucleated polychromatic erythrocytes (MNPCE) observed in bone marrow cells of female (F) and male (M) Swiss mice treated with Tamarindus indica extract, and respective controls.

\begin{tabular}{|c|c|c|c|c|c|c|c|c|c|}
\hline \multirow[t]{2}{*}{ Treatment } & \multirow{2}{*}{$\begin{array}{c}\text { Dose } \\
(\mathrm{mg} / \mathrm{kg})\end{array}$} & \multicolumn{6}{|c|}{ Number of MNPCE per animal } & \multirow{2}{*}{$\begin{array}{c}\text { MNPCE } \\
(\text { mean } \pm \text { SD) }\end{array}$} & \multirow{2}{*}{$\begin{array}{c}\mathrm{PCE} / \mathrm{NCE} \\
(\mathrm{mean} \pm \mathrm{SD})\end{array}$} \\
\hline & & $\mathrm{F}_{1}$ & $\mathrm{~F}_{2}$ & $\mathrm{~F}_{3}$ & $\mathrm{M}_{1}$ & $\mathrm{M}_{2}$ & $\mathrm{M}_{3}$ & & \\
\hline Negative control (water) & 0 & 2 & 1 & 1 & 2 & 2 & 2 & $1.66 \pm 0.51$ & $0.30 \pm 0.04$ \\
\hline T. indica extract & 1000 & 2 & 4 & 4 & 1 & 1 & 2 & $2.33 \pm 1.36$ & $0.20 \pm 0.12$ \\
\hline T. indica extract & 1500 & 3 & 5 & 6 & 3 & 4 & 2 & $3.83 \pm 1.47$ & $0.19 \pm 0.11$ \\
\hline T. indica extract & 2000 & 7 & 9 & 5 & 6 & 7 & 6 & $6.66 \pm 1.36^{*}$ & $0.28 \pm 0.12$ \\
\hline $\begin{array}{l}\text { Positive control } \\
\text { (cyclophosphamide) }\end{array}$ & 50 & 14 & 14 & 19 & 13 & 13 & 12 & $14.16 \pm 2.48^{*}$ & $0.28 \pm 0.12$ \\
\hline
\end{tabular}

Two thousand cells were analyzed per animal. $\mathrm{NCE}=$ normochromatic erythrocytes. $*$ Significantly different from negative control $(\mathrm{P}<0.001)$.

The PCE/NCE ratio of the T. indica-treated groups, the positive control group, and the negative control group was not significantly different, indicating that the extract does not induce suppression of bone marrow cell proliferation (Table 1, P > 0.05).

The viability of the cells used in the comet assay was higher than $80 \%$ (data not shown). The results of the comet assay, namely, data on the total number of DNA damaged cells and scores for the Wistar rats dosed with 1000, 1500, and $2000 \mathrm{mk} / \mathrm{kg}$, as well as the negative and positive controls (50 mg/kg cyclophosphamide), are presented in Tables 2 and 3 . As expected, cyclophosphamide, the positive control, induced a significant increase in DNA migration in leukocytes and liver cells $(\mathrm{P}<0.001)$. No statistically significant differences were observed between $T$. indica-treated $v s$ untreated animals at the three doses tested, on both the leukocytes and the liver cell samples analyzed, although an increase in the total cells with 
DNA damage was observed at the two higher doses tested. At the doses that induced some increase in DNA damage, the majority of the damaged cells showed minor damage (class 1) and very few showed high amounts of damage (classes 2 and 3). Also as expected, cyclophosphamide produced an increase in DNA damage to the liver and leukocyte cells $(\mathrm{P}<0.001)$.

\begin{tabular}{|c|c|c|c|c|c|c|c|}
\hline \multirow[t]{2}{*}{ Treatment } & \multirow[t]{2}{*}{ Animals } & \multirow[t]{2}{*}{ Total $^{1}$} & \multicolumn{4}{|c|}{ Comet class } & \multirow[t]{2}{*}{ Score } \\
\hline & & & 0 & 1 & 2 & 3 & \\
\hline \multirow[t]{7}{*}{ Control } & $F_{1}$ & 4 & 96 & 3 & 1 & 0 & 5 \\
\hline & $\mathrm{F}_{2}$ & 3 & 97 & 2 & 1 & 0 & 4 \\
\hline & $\mathrm{F}_{3}$ & 4 & 96 & 3 & 1 & 0 & 5 \\
\hline & $\mathrm{M}_{1}$ & 6 & 94 & 2 & 2 & 2 & 12 \\
\hline & $\mathrm{M}_{2}$ & 1 & 99 & 0 & 0 & 1 & 3 \\
\hline & $M_{3}$ & 2 & 98 & 1 & 0 & 1 & 4 \\
\hline & Mean \pm SD & & & & & & $5.5 \pm 3.27$ \\
\hline T. indica extract & $F_{1}$ & 7 & 93 & 2 & 3 & 2 & 14 \\
\hline \multirow[t]{6}{*}{$(1000$ mg/kg) } & $\mathrm{F}_{2}$ & 4 & 96 & 3 & 1 & 0 & 5 \\
\hline & $\mathrm{F}_{3}$ & 6 & 94 & 4 & 1 & 1 & 9 \\
\hline & $\mathrm{M}_{1}$ & 9 & 91 & 7 & 2 & 0 & 11 \\
\hline & $\mathrm{M}_{2}$ & 1 & 99 & 1 & 0 & 0 & 1 \\
\hline & $M_{3}$ & 4 & 96 & 4 & 0 & 0 & 4 \\
\hline & Mean \pm SD & & & & & & $7.33 \pm 4.84$ \\
\hline \multirow{7}{*}{$\begin{array}{l}\text { T. indica extract } \\
(1500 \mathrm{mg} / \mathrm{kg})\end{array}$} & $\mathrm{F}_{1}$ & 11 & 89 & 8 & 3 & 0 & 14 \\
\hline & $\mathrm{F}_{2}$ & 9 & 91 & 7 & 2 & 0 & 11 \\
\hline & $\mathrm{F}_{3}$ & 10 & 90 & 9 & 1 & 0 & 11 \\
\hline & $\mathrm{M}_{1}$ & 13 & 87 & 9 & 3 & 1 & 18 \\
\hline & $\mathrm{M}_{2}$ & 8 & 92 & 7 & 1 & 0 & 9 \\
\hline & $M_{3}$ & 9 & 91 & 8 & 1 & 0 & 10 \\
\hline & Mean \pm SD & & & & & & $12.16 \pm 3.31$ \\
\hline T. indica extract & $\mathrm{F}_{1}$ & 5 & 95 & 5 & 0 & 0 & 5 \\
\hline \multirow[t]{6}{*}{$(2000 \mathrm{mg} / \mathrm{kg})$} & $\mathrm{F}_{2}$ & 8 & 92 & 6 & 2 & 0 & 10 \\
\hline & $\mathrm{F}_{3}$ & 7 & 93 & 7 & 0 & 0 & 7 \\
\hline & $\mathrm{M}_{1}$ & 13 & 97 & 10 & 3 & 0 & 16 \\
\hline & $\mathrm{M}_{2}$ & 8 & 92 & 8 & 0 & 0 & 8 \\
\hline & $\mathrm{M}_{3}$ & 6 & 94 & 6 & 0 & 0 & 6 \\
\hline & Mean \pm SD & & & & & & $8.66 \pm 3.98$ \\
\hline Cyclophosphamide & $\mathrm{F}_{1}$ & 45 & 55 & 25 & 12 & 8 & 73 \\
\hline \multirow[t]{5}{*}{$(50$ mg/kg) } & $\mathrm{F}_{2}$ & 30 & 70 & 18 & 8 & 4 & 46 \\
\hline & $\mathrm{F}_{3}$ & 36 & 64 & 21 & 7 & 8 & 59 \\
\hline & $\mathrm{M}_{1}$ & 26 & 74 & 18 & 5 & 3 & 37 \\
\hline & $\mathrm{M}_{2}$ & 32 & 68 & 22 & 7 & 3 & 45 \\
\hline & $\begin{array}{c}M_{3} \\
\text { Mean } \pm \text { SD }\end{array}$ & 52 & 48 & 28 & 18 & 6 & $\begin{array}{c}84 \\
57.3 \pm 18.1^{*}\end{array}$ \\
\hline
\end{tabular}

${ }^{1}$ Total number of damaged cells (classes $\left.1+2+3\right)$. ${ }^{*}$ Significantly different from the negative control $(\mathrm{P}<0.001)$.

The crude tamarind extract used in the present study contains a predominance of compounds such as flavonoids, which normally occur as secondary metabolites in plants. The extract was found to be rich in sugars $(70.25 \pm 8.56 \mathrm{mg} / \mathrm{mL})$, polyphenols $(34.02 \pm$ $2.11 \mathrm{nmol} / \mathrm{mL})$ and flavonoids $(35.51 \pm 5.61 \mu \mathrm{g} / \mathrm{mL})$, the last two being well-known antioxidant agents (Martinello et al., 2006). 


\begin{tabular}{|c|c|c|c|c|c|c|c|}
\hline \multirow[t]{2}{*}{ Treatment } & \multirow[t]{2}{*}{ Animals } & \multirow[t]{2}{*}{ Total $^{1}$} & \multicolumn{4}{|c|}{ Comet class } & \multirow[t]{2}{*}{ Score } \\
\hline & & & 0 & 1 & 2 & 3 & \\
\hline \multirow[t]{7}{*}{ Control } & $\mathrm{F}_{1}$ & 1 & 99 & 0 & 0 & 1 & 3 \\
\hline & $\mathrm{F}_{2}$ & 4 & 96 & 3 & 1 & 0 & 5 \\
\hline & $\mathrm{F}_{3}$ & 5 & 95 & 4 & 1 & 0 & 6 \\
\hline & $M_{1}$ & 7 & 93 & 3 & 2 & 2 & 13 \\
\hline & $\mathrm{M}_{2}$ & 1 & 99 & 1 & 0 & 0 & 1 \\
\hline & $\mathrm{M}_{3}^{2}$ & 3 & 97 & 2 & 0 & 1 & 5 \\
\hline & Mean \pm SD & & & & & & $5.5 \pm 4.08$ \\
\hline \multirow{7}{*}{$\begin{array}{l}\text { T. indica extract } \\
(1000 \mathrm{mg} / \mathrm{kg})\end{array}$} & $\mathrm{F}_{1}$ & 1 & 99 & 1 & 0 & 0 & 1 \\
\hline & $\mathrm{F}_{2}$ & 2 & 98 & 2 & 0 & 0 & 2 \\
\hline & $\mathrm{F}_{3}^{2}$ & 7 & 93 & 6 & 1 & 0 & 8 \\
\hline & $\mathrm{M}_{1}$ & 3 & 97 & 2 & 1 & 0 & 4 \\
\hline & $\mathrm{M}_{2}$ & 3 & 97 & 3 & 0 & 0 & 3 \\
\hline & $\mathrm{M}_{3}$ & 4 & 96 & 3 & 1 & 0 & 5 \\
\hline & Mean \pm SD & & & & & & $3.83 \pm 2.48$ \\
\hline \multirow{7}{*}{$\begin{array}{l}\text { T. indica extract } \\
(1500 \mathrm{mg} / \mathrm{kg})\end{array}$} & $\mathrm{F}_{1}$ & 13 & 87 & 10 & 3 & 0 & 16 \\
\hline & $\mathrm{F}_{2}$ & 11 & 89 & 11 & 0 & 0 & 11 \\
\hline & $\mathrm{F}_{3}$ & 9 & 91 & 8 & 1 & 0 & 10 \\
\hline & $\mathrm{M}_{1}$ & 10 & 90 & 9 & 1 & 0 & 11 \\
\hline & $\mathrm{M}_{2}$ & 12 & 88 & 9 & 2 & 1 & 16 \\
\hline & $\mathrm{M}_{3}^{2}$ & 8 & 92 & 7 & 1 & 0 & 9 \\
\hline & Mean \pm SD & & & & & & $12.16 \pm 3.06$ \\
\hline \multirow{7}{*}{$\begin{array}{l}\text { T. indica extract } \\
(2000 \mathrm{mg} / \mathrm{kg})\end{array}$} & $\mathrm{F}_{1}$ & 15 & 85 & 10 & 5 & 0 & 20 \\
\hline & $\mathrm{F}_{2}$ & 13 & 87 & 13 & 0 & 0 & 13 \\
\hline & $\mathrm{F}_{3}$ & 6 & 94 & 6 & 0 & 0 & 6 \\
\hline & $M_{1}$ & 10 & 90 & 6 & 4 & 0 & 14 \\
\hline & $\mathrm{M}_{2}$ & 15 & 85 & 8 & 7 & 0 & 22 \\
\hline & $\mathrm{M}_{3}^{2}$ & 9 & 91 & 9 & 0 & 0 & 9 \\
\hline & Mean \pm SD & & & & & & $14.0 \pm 6.16$ \\
\hline \multirow{7}{*}{$\begin{array}{l}\text { Cyclophosphamide } \\
(50 \mathrm{mg} / \mathrm{kg})\end{array}$} & $\mathrm{F}_{1}$ & 40 & 60 & 16 & 13 & 11 & 75 \\
\hline & $\mathrm{F}_{2}$ & 35 & 65 & 20 & 6 & 9 & 59 \\
\hline & $\mathrm{F}_{3}$ & 50 & 50 & 20 & 12 & 18 & 98 \\
\hline & $\mathrm{M}_{1}$ & 31 & 69 & 22 & 7 & 2 & 42 \\
\hline & $\mathrm{M}_{2}$ & 33 & 67 & 22 & 8 & 3 & 47 \\
\hline & $\mathrm{M}_{3}^{2}$ & 55 & 45 & 26 & 14 & 15 & 99 \\
\hline & Mean \pm SD & & & & & & $70.0 \pm 24.83 *$ \\
\hline
\end{tabular}

${ }^{1}$ Total number of damaged cells (classes $\left.1+2+3\right)$. Significantly different from the negative control $(\mathrm{P}<0.001)$.

The screening tests carried out by Ramos et al. (2003) with $T$. indica bark extract indicate that the antioxidant potential demonstrated in biochemical assays does not confer protection to the cellular genome against oxidative stress per se, resulting in an ineffective antimutagen in Escherichia coli. On the other hand, Martinello et al. (2006) observed that the fruit pulp extract of $T$. indica showed radical scavenging ability in vitro, and improved the efficiency of the antioxidant defense system in vivo when the tamarind extract was administered at a concentration of $5 \%$.

Considering that the three $T$. indica extract doses tested in the present study are much higher than the $5 \%$ concentration usually present in juice consumed by the human population (Martinello et al., 2006), we conclude that T. indica fruit pulp extract did not induce clastogenic/ aneugenic or cytotoxic effects or DNA damage. This was supported by results obtained using 
two different experimental models (Mus musculus and Rattus norvegicus). In an in vivo assay performed with the endogenous activation system, no effect of liver enzymes was seen. This indicates that this plant extract does not contain compounds that can be activated to produce genotoxic metabolites. However, given that the $2000 \mathrm{mg} / \mathrm{kg}$ dose produced a significant increase in the number of MNPCEs, caution is needed with the intake of high or cumulative doses of this extract.

\section{ACKNOWLEDGMENTS}

Research supported by the Fundação de Amparo à Pesquisa do Estado de São Paulo (FAPESP \#2006/57514-2), FAPEMIG (Rede Mineira de Ensaios Toxicológicos e Farmacológicos de Produtos Terapêuticos, EDT \#1879/02) and CNPq (\#306544/2006-7).

\section{REFERENCES}

Andraws R, Chawla P and Brown DL (2005). Cardiovascular effects of ephedra alkaloids: a comprehensive review. Prog. Cardiovasc. Dis. 47: 217-225.

Hartmann A and Speit G (1997). The contribution of cytotoxicity to DNA - effects in the single cell gel test (comet assay). Toxicol. Lett. 90: 183-188.

Joyeux M, Mortier F and Flurentin J (1995). Screening of antiradical, antilipoperoxidant and hepatoprotective effects of nine plant extracts used in Caribbean folk medicine. Phytother. Res. 9: 228-230.

Klaude M, Eriksson S, Nygren J and Ahnstrom G (1996). The comet assay: mechanisms and technical considerations. Mutat. Res. 363: 89-96.

Komutarin T, Azadi S, Butterworth L, Keil D, et al. (2004). Extract of the seed coat of Tamarindus indica inhibits nitric oxide production by murine macrophages in vitro and in vivo. Food Chem. Toxicol. 42: 649-658.

Landi Librandi AP, Chrysostomo TN, Azzolini AE, Recchia CG, et al. (2007). Effect of the extract of the tamarind (Tamarindus indica) fruit on the complement system: studies in vitro and in hamsters submitted to a cholesterolenriched diet. Food Chem. Toxicol. 45: 1487-1495.

Maiti R, Jana D, Das UK and Ghosh D (2004). Antidiabetic effect of aqueous extract of seed of Tamarindus indica in streptozotocin-induced diabetic rats. J. Ethnopharmacol. 92: 85-91.

Martinello F, Soares SM, Franco JJ, Santos AC, et al. (2006). Hypolipemic and antioxidant activities from Tamarindus indica L. pulp fruit extract in hypercholesterolemic hamsters. Food Chem. Toxicol. 44: 810-818.

Pumthong G (1999). Antioxidant Activity of Polyphenolic Compounds Extracted from Seed Coat of Tamarindus indica Linn. Chiang Mai University, Thailand.

Ramos A, Visozo A, Piloto J, Garcia A, et al. (2003). Screening of antimutagenicity via antioxidant activity in Cuban medicinal plants. J. Ethnopharmacol. 87: 241-246.

Rimbau V, Cerdan C, Vila R and Iglesias J (1999). Antiinflammatory activity of some extracts from plants used in the traditional medicine of north-African countries (II). Phytother. Res. 13: 128-132.

Schmid W (1976). The Micronucleous Test for Cytogenetic Analysis. Vol. 4. In: Chemical Mutagenesis, Principles and Methods for their Detection (Hollaender A, ed.). Plenum Press, New York, 31-53.

Singh NP, McCoy MT, Tice RR and Schneider EL (1988). A simple technique for quantitation of low levels of DNA damage in individual cells. Exp. Cell Res. 175: 184-191.

Sokal RR and Rohlf FJ (1995). The Principles and Practice of Statistics in Biology Research. In: Biometry. W.H. Freeman, San Francisco, 175-205, 404-486.

Speit G and Hartmann A (1999). The Comet Assay (Single-Cell Gel Test): A Sensitive Genotoxicity Test for the Detection of DNA Damage and Repair. In: DNA Repair Protocols: Eukaryotic Systems. Ser. Methods in Molecular Biology (Henderson DS, ed.). Vol. 113. Humana Press Inc., Totowa, 203-212.

Tsuda T, Watanable M, Ohshima K, Yamamoto A, et al. (1994). Antioxidative components isolated from the seed of tamarind (Tamarindus indica L.). J. Agric. Food Chem. 42: 2671-2674. 